\title{
Angiotensin II receptor blockers and insulin resistance
}

\author{
Leonardina Ciccarelli
}

Hypertension Research (2010) 33, 779; doi:10.1038/hr.2010.99; published online 10 June 2010

$\mathrm{T}$ he growing concern about the increasing prevalence of the metabolic syndrome and type 2 diabetes mellitus has generated substantial interest in the metabolic effects of antihypertensive drugs. ${ }^{1,2}$ The metabolic syndrome is strongly associated with insulin resistance and consists of a constellation of factors such as hypertension and hyperlipidemia that raise the risk for cardiovascular diseases and diabetes mellitus. ${ }^{3}$ Several kinds of hypotensive drugs, such as thiazide diuretics and $\beta$-blockers, have been reported to impair insulin sensitivity. ${ }^{4,5}$ Conversely, it has been recognized that angiotensin-converting enzyme (ACE) inhibition and some angiotensin II receptor blockers improve insulin sensitivity in essential hypertension, suggesting an important role for the suppression of angiotensin II generation in improving insulin sensitivity and decreasing the risk for type 2 diabetes mellitus. Interruption of the renin-angiotensin system with ACE inhibitors or angiotensin II type 1 receptor blockers has been shown to prevent the onset of diabetes in hypertensive patients and to reduce cardiovascular and renal disease progression in diabetic patients with hypertension. ${ }^{6,7}$ In vitro, experiments and studies in animals and in humans have suggested a possible relationship between the reninangiotensin system and the pathogenesis of insulin resistance. A possible mechanism by which angiotensin II receptor blockers ameliorate insulin resistance is the stimulation of angiotensin type 2 receptors and the resultant increase in nitric oxide production. Other possible mechanisms of improved insulin sensitivity by angiotensin receptor antagonism include vasodilation, which increases the blood flow in skeletal muscles; activation of the glucose transporter and its translocation from an intracellular membrane compartment to a plasma membrane fraction; and suppression of the noradrenaline release induced by angiotensin II antagonism.

Not all the angiotensin II receptor blockers have the same effect on insulin resistance; olmesartan, for example, has been reported to prevent endothelin-1-induced hypertension and the formation of reactive oxygen species. ${ }^{8}$ Some other studies, instead, showed that candesartan improves insulin resistance in patients with essential hypertension, through ACE inhibition.

In this context, the article written by Derosa et al. ${ }^{9}$ is a valid example of how two angiotensin II receptor blockers, like candesartan and olmesartan, can have different actions on insulin resistance.

In this study, 194 Caucasian patients, hypertensive, and with well-controlled type 2 diabetes mellitus, were randomized to take candesartan or olmesartan for 1 year. The authors observed that, beyond similar antihypertensive and anti-inflammatory effects, only candesartan, but not olmesartan, exerts specific effects on adipose tissue metabolism, improving the $M$ value, adiponectin, resistin, retinol binding protein-4, visfatin, and vaspin levels, confirming what has already reported by de Vinuesa et al. ${ }^{10}$ in patients with chronic kidney diseases.

These observations need to be considered during clinical practice to better control the metabolic syndrome and its implications on cardiovascular risk.

1 Zimmet P, Alberti KG, Shaw J. Global and societal implications of the diabetes epidemic. Nature 2001; 414: 782-787.

2 Padwal R, Laupacis A. Antihypertensive therapy and incidence of type 2 diabetes: a systematic review. Diabetes Care 2004; 27: 247-255.

3 Eckel RH, Grundy SM, Zimmet PZ. The metabolic syndrome. Lancet 2005; 365: 1415-1428.

4 Pollare $\mathrm{T}$, Lithell $\mathrm{H}$, Berne $\mathrm{C}$. A comparison of the effects of hydrochlorothiazide and captopril on glucose and lipid metabolism in patients with hypertension. N Engl J Med 1989; 321: 868-873.

5 Pollare T, Lithell H, Mörlin C, Präntare H, Hvarfner A, Ljunghall $S$. Metabolic effects of diltiazem and atenolol: results from a randomized, double-blind study with parallel groups. J Hypertens 1989; 7: 551-559.

6 Ferrannini E, Buzzigoli G, Bonadonna R, Giorico MA, Oleggini M, Graziadei L, Pedrinelli R, Brandi L, Bevilacqua S. Insulin resistance in essential hypertension. N Engl J Med 1987; 316: 350-355.

7 Alkharouf J, Nalinikumari K, Corry D, Tuck M. Long-term effects of the angiotensin converting enzyme inhibitor captopril on metabolic control in noninsulin dependent diabetes mellitus. Am J Hypertens 1993; 6: 337-343.

8 Yao L, Kobori H, Rahman M, Seth DM, Shokoji T, Fan Y, Zhang GX, Kimura S, Abe Y, Nishiyama A. Olmesartam improves endothelin-induced hypertension and oxidative stress in rats. Hypertens Res 2004; 27: 493-500.

9 Derosa G, Maffioli P, Salvadeo SAT, Ferrari I, Gravina A, Mereu R, Palumbo I, Fogari E, D'Angelo A, Cicero AFG. Differential effect of candesartan and olmesartan on adipose tissue activity biomarkers in type 2 diabetic hypertensive patients. Hypertens Res 2010; 33: 790-795.

10 de Vinuesa SG, Goicoechea M, Kanter J, Puerta M, Cachofeiro V, Lahera V, Gómez-Campderá F, Luño J. Insulin resistance, inflammatory biomarkers, and adipokines in patients with chronic kidney disease: effects of angiotensin II blockade. J Am Soc Nephrol 2006; 17 (Suppl 3): S206-S212. 